\title{
Effects of alginate oligosaccharides treatment on preservation and fresh-keeping mechanism of shrimp during frozen storage
}

\author{
Fen YAN ${ }^{1 \star}$, Mei WANG ${ }^{1}$, Xinghang $\mathrm{CHEN}^{1}$, Xiaoyue $\mathrm{LI}^{1}$, Yiqun WU ${ }^{1}$, Caili FU ${ }^{1,2}$
}

\begin{abstract}
In this study, we investigated the influence of alginate oligosaccharides (AOS) coating on the quality of white shrimp (P. vannamei) at $4 \pm 1{ }^{\circ} \mathrm{C}$. We measured shrimp quality by surveying changes in certain properties, such as sensory quality, the microbiota, total volatile basic nitrogen (TVB-N), pH, and sensory characteristics. Compared to control group, AOS coating effectively stopped the growth of bacteria and decreased the formation of TVB-N (from $40 \%$ down to $30 \%$ ). The $\mathrm{pH}$ of samples treated with AOS was visibly lower than that of the control group. The sensory quality of the AOS coated shrimp resembled microbial and physicochemical properties, and the acceptability was improved. Furthermore, we found the abundance of spoilage microorganisms, such as Shewanella and Pseudoalteromonas, in AOS coated groups is reduced compared to control groups. All these results suggest that our AOS coating treatment may improve storage and preservation of frozen shrimp.
\end{abstract}

Keywords: alginate oligosaccharides; shelf life; bacterial diversity; microbial communities; preservation.

Practical Application: The preservation effect of AOS coating on shrimp.

\section{Introduction}

Alginate is a polysaccharide consisting of mannuronic and guluronic acids. The polymers of alginate can exist as either homopolymeric sequences of $\mathrm{G}$ blocks (GG), M blocks (MM), or as a heteropolymeric sequence containing alternating structures of $M$ and G blocks (MG) (Haug et al., 1974). Alginate is found in brown algae and makes up a large amount of intracellular material while also being present in cell wall. Alginate and its derivatives are generally used in food, agriculture, and pharmaceutical industries due to their gelling ability, stability, and high viscosity (Ci et al., 1999; Johnson et al., 1997).

Alginate lyase is an enzyme that catalyzes the degradation of alginate and exists in a variety of organisms including bacteria, fungi, brown algae, ect. (Rahman et al., 2010; Singh et al., 2011; Wang et al., 2013). Alginate lyase has broad applications, for example in the production of alginate-derived bioactive oligosaccharides (Natsume et al., 1994; Kawada et al., 1997; Iwamoto et al., 2005), treatment of patients infected with mucinous Pseudomonas aeruginosa biofilm (Alkawash et al., 2006) and the isolation of protoplasts from marine algae (Sawabe et al., 1993). Alginate can be depolymerized into alginate oligosaccharide (AOS), which has certain advantages over some chemical and physical methods. These advantages include high yields and the production of specific oligosaccharides (Boucelkha et al., 2016). Recent reports have shown that alginate hydrolysates and their derivatives can promote plant growth and prevent dental cavities. These compounds also show anti-oxidant, anti-tumor, antimicrobial, anti-coagulatory, anti-inflammatory, and immunomodulatory activity (Hu et al., 2004; Miura et al., 2001).
Shrimp have many beneficial organic compounds, such as polyunsaturated fatty acids, amino acids, and peptides. Commercial shrimp can be highly perishable which leads to significant odor and soft texture. This perishability is due to microbial growth and lipid oxidation, which mainly causes the deterioration in the quality of such products (Mastromatteo et al., 2011). Recently, a combined treatment of antibiotics and functional marine oligosaccharides has received increasing attention due to increased demand for health safety (He et al., 2014). As consumer demand for shrimp continues to increase, they are increasingly concerned about the preservation of shrimp. In modern society, the demand for healthy and green food has also increased. Therefore, major focus of the industry has been to develop more biological preservatives to replace chemical preservatives. Thus an increasing amount of research has been directed at the development of natural preservatives to improve shelf life of aquatic products. Two preservatives widely used in food and medicine are chitosan oligosaccharide (COS) and alginate-derived oligosaccharides (ADO) due to their physiological characteristics. ADO is a product of sodium alginate degradation by alginate lyase (Blackwood et al., 1983). However, alginate lyase enzyme activity is reduced at cold temperatures which conflicts with refrigeration storage of aquatic products being one of the main long-term preservation methods. Refrigeration is important since it deters microbial growth while maintaining mouthfeel and nutrient content. However, ADO treatment does not necessarily improve product quality (Gonçalves \& Gindri, 2009). Thus, further research is necessary to determine the effect of AOS coating on preservation of shrimp. Alginate hydrolysates and their derivatives possess important properties, which make them a promising candidate for future applications. 
Here we isolated a marine bacterium classified as Flavobacterium sp. strain B2 (described below in detail) from kelp's or abalone's viscera. This bacterium produces alginate lyase enzyme that acts on sodium alginate. The AOS treatment prepared by enzymatic hydrolysis can have a positive effect on the preservation of shrimp, which provides a mechanism for bio-preservation technology.

\section{Materials and methods}

\subsection{Shrimp sample preparation}

The white shrimp ( $P$. vannamei) were purchased from Fuqing Yihua Food Co., Ltd. (Fujian, China). Fresh live shrimp were shipped to the lab within 30 minutes and remained alive before experiment. The shrimp were killed with crushed ice and washed with deionized water. Shrimp were soaked based on size for $30 \mathrm{~min}$ with sterile distilled water and AOS. Samples treated with different solutions were randomly divided into ziplock bags and placed at $4 \pm 1^{\circ} \mathrm{C}$ for quality evaluation.

\subsection{Preparation of AOS}

Bacteria was fermented to get alginate lyase, which was precipitated by ammonium sulfate and dialyzed to get crude protein. Crude protein was filtered by $0.22 \mu \mathrm{m}$ filter membrane and loaded first onto a DEAE-650C column $(1.6 \times 25 \mathrm{CM})$ from American GE Ltd pre-equilibrated with phosphate buffer (PB) (20 mM, pH 8.0). Unbound protein was removed by rinsing with the $\mathrm{PB}$ buffer. Bound protein was eluted with a linear gradient from $0 \mathrm{M}$ to $0.25 \mathrm{M}$ sodium chloride $(\mathrm{NaCl})$ in $\mathrm{PB}$ buffer $(20 \mathrm{mM}$, $\mathrm{pH}$ 8.0). Finally, the column was eluted with $1 \mathrm{M} \mathrm{NaCl}$ in $\mathrm{PB}$ buffer (20 mM, pH 8.0). Each fraction was tested for enzyme activity. The fraction displaying peak enzyme activity was analyzed by SDS-PAGE $(12.5 \% \mathrm{~T}, 5 \% \mathrm{C})$, and the active fraction loaded onto a Sephacryl S-200 column $(1.6 \times 100 \mathrm{CM})$ pre-equilibrated with PB (20 mM, pH 8.0) before loading. $20 \mathrm{~g} / \mathrm{L}$ of sodium alginate was degraded by alginate lyase to obtain AOS.

\subsection{Physicochemical analysis}

\section{Sensory evaluation}

The sensory evaluation of shrimp was conducted according to the methods (Erickson et al., 2007; Xu et al., 2014a; Chen et al., 2019) with some changes. The aroma, color and muscle tissue of shrimp samples were evaluated by analysis panel consisting of eight panelists. The sensory quality of the shrimp was comprehensively scored. The score is 10 points. The 9 points or higher are strongly acceptable, the 7-9 points are a slightly acceptable range, and the 6-7 points are acceptable. 5-6 points are unacceptable, and less than 5 points are completely unacceptable.

\section{Texture Profile Analysis (TPA)}

TPA determination of shrimp was performed using a texture analyzer (TA-XT plus, UK). The $\mathrm{P} / 5(\mathrm{~d}=5 \mathrm{~mm})$ cylindrical probe was used on the second and the third abdominal section of shrimp, with a deformation of $40 \%$ and a test speed of $1 \mathrm{~mm} / \mathrm{s}$.

\section{Determination of $p H$}

To determine $\mathrm{pH}$ of the shrimp after coating, $2 \mathrm{~g}$ of minced shrimp was homogenized with $20 \mathrm{~mL}$ of distilled water for 30 minutes, and the homogenate was filtered. $\mathrm{pH}$ was measured using a digital STARTER 2100 pH meter (OHRUS, Shanghai, China).

\section{Determination of TVB-N}

The TVB-N values were calculated by the GB 5009.228-2016 method. $2 \mathrm{~g}$ of minced shrimp was homogenized with $4 \mathrm{~mL}$ distilled water and $16 \mathrm{~mL}$ of $2 \mathrm{~g} / \mathrm{L}$ trichloroacetic acid (TCA). The mixture was incubated for 30 minutes and then filtered. A $2 \mathrm{~mL}$ filter and $5 \mathrm{~mL}$ of a $1 \%(\mathrm{~m} / \mathrm{v})$ magnesium oxide $(\mathrm{MgO})$ solution was added to the reactor, respectively. The distillation was collected in a flask containing $10 \mathrm{~mL}$ of a $10 \mathrm{~g} / \mathrm{L}$ aqueous solution of boric acid and then mixed with an indicator containing $30 \mu \mathrm{L}$ of $1 \mathrm{~g} / \mathrm{L}$ methyl red and $170 \mu \mathrm{L}$ of $1 \mathrm{~g} / \mathrm{L}$ bromocresol green. $0.1 \mathrm{M}$ hydrochloric acid solution was used to titrate the solution. The TVB-N value is shown in milligrams of nitrogen $(1 \mathrm{mg} / 100 \mathrm{~g})$ per $100 \mathrm{~g}$ of sample.

\section{Determination of $K$-value}

Adenosine triphosphate (ATP) and its degradation products were measured by the improved method of SC/T 3048-2014. $2 \mathrm{~g}$ of chopped shrimp were homogenized with $20 \mathrm{~mL}$ of $10 \%$ $(\mathrm{v} / \mathrm{v})$ cold perchloric acid and then centrifuged at 10,000 $\mathrm{x} g$ for $10 \mathrm{~min}$. The analyte in the precipitate was extracted with $10 \mathrm{~mL}$ of $5 \%(\mathrm{v} / \mathrm{v})$ cold perchloric acid and centrifuged at 10,000 x g for $10 \mathrm{~min}$. The $\mathrm{pH}$ of the two supernatants was adjusted to 6.0 to 6.4 using $10 \mathrm{M}$ sodium hydroxide $(\mathrm{NaOH})$, followed by centrifugation at $10,000 \mathrm{x}$ for $10 \mathrm{~min}$. The supernatants were filtered with a $0.22 \mu \mathrm{m}$ membrane filter. The peak at $254 \mathrm{~nm}$ was detected by HPLC technique. $0.02 \mathrm{M} \mathrm{PB}$ ( $\mathrm{pH}$ 6.0) was used as the mobile phase. The Formula 1 to determine $\mathrm{K}$-values is as follows:

$K$ Value $(\%)=[(H x R)+(H x)] /[(A T P)+(A D P)+(A M P)+(I M P)+(H x R)+(H x)] \times 100$

where ATP is adenosine triphosphate concentration in the sample $(\mu \mathrm{mol} / \mathrm{g})$; ADP is adenine diphosphate concentration in the sample $(\mu \mathrm{mol} / \mathrm{g}) ; \mathrm{AMP}$ is adenylate concentration in the sample $(\mu \mathrm{mol} / \mathrm{g})$; IMP is inosine concentration in the sample $(\mu \mathrm{mol} / \mathrm{g}) ; \mathrm{HxR}$ is the concentration of hypoxanthine nucleoside in the sample $(\mu \mathrm{mol} / \mathrm{g}) ; \mathrm{Hx}$ is the concentration of hypoxanthine in the sample $(\mu \mathrm{mol} / \mathrm{g})$.

\subsection{Microbial analysis}

\section{Microbiological analysis}

Microbiological analysis was performed according to the method of GB/T 4789.2-2008. Shrimp was homogenized in a $90 \mathrm{~mL} 0.9 \%$ sterile physiological saline solution by a stomacher stirrer for $2 \mathrm{~min}$. The resulting mixture was serially diluted in a $1: 10$ ratio in sterile saline. $0.1 \mathrm{~mL}$ of the appropriate dilution was plated in triplicate on LB agar plates and incubated at $30^{\circ} \mathrm{C}$ for 48 hours. Total bacterial count (TBC) was measured and expressed by log CFU/g.

\section{Microbial diversity analysis}

Total genomic DNA extraction kit (Sangon Biotech, Shanghai, China) following manufacturer instructions. High-throughput sequencing of extracted DNA was carried out using Illumina Hiseq2500 system (Illumina, San Diego, CA, USA). The reads from the original DNA fragments were merged by Base Calling analysis and the results were stored in FASTQ file format, which includes reads information and its corresponding sequencing quality information. 
CD-HIT was used for clustering raw sequences into operational taxonomic units (OTUs) at a 97\% similarity level. The OTU statistics and graphical output were conducted in $\mathrm{R}$ program version 1.8.0. The microbial communities were examined by using network analysis and Pearson rank correlations.

\subsection{Statistical analysis}

Each experiment was repeated three times. Data was processed using Origin 8.5. Data is displayed as mean \pm SD. Statistical significance was analyzed by one-way analysis of variance (ANOVA) using SPSS 17.0 (Chicago, IL, USA). $\mathrm{p}=0.05$ was set to a statistically significant level.

\section{Results and discussion}

\subsection{Physicochemical analysis}

Preparation of $A O S$

Bacteria was grown in a $250 \mathrm{~mL}$ flask and alginate lyase was purified via electrophoretic homogeneity by two-step ion exchange chromatography and gel filtration chromatography. Purified fractions show a single band in SDS-PAGE with the correct corresponding molecular weight of approximately $80 \mathrm{kDa}$ (Figure 1, lane 5). AOS was obtained by purified alginate lyase degradation of alginate at $30^{\circ} \mathrm{C}$ and $\mathrm{pH}$ 8.0.

\section{Sensory evaluation}

There was no obvious difference between shrimps treated AOS and the control group on the 2nd day (Table 1). On the 4 th day, the sensory score of shrimps treated AOS was 8.38, which was higher than that of the control group. On the 6th day, the treated group score of 7.81 was still within the acceptance, significantly higher than the control group score of 5.81. On the 8 th day, the control group score of 3.44 was less than a strongly unacceptable degree, but the treated group score of 6.06 was

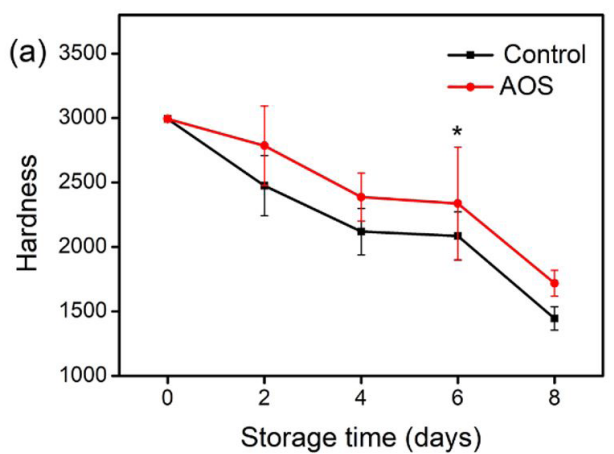

acceptance. Thus, the results implied that the group treated AOS can extend the shelf life of the shrimps by 2 days.

Values were expressed using means \pm standard deviation. Different letters in each data indicate a statistically significant different $(\mathrm{p}<0.05)$.

\section{Texture Profile Analysis (TPA)}

From the perspective of consumer acceptability, texture is a very important sensory indicator. Shrimp was coated by AOS or stored in distilled $\mathrm{H} 20$ to evaluate their quality after storage at $4 \pm 1{ }^{\circ} \mathrm{C}$ for 8 days. As shown in Figure 2, the hardness and

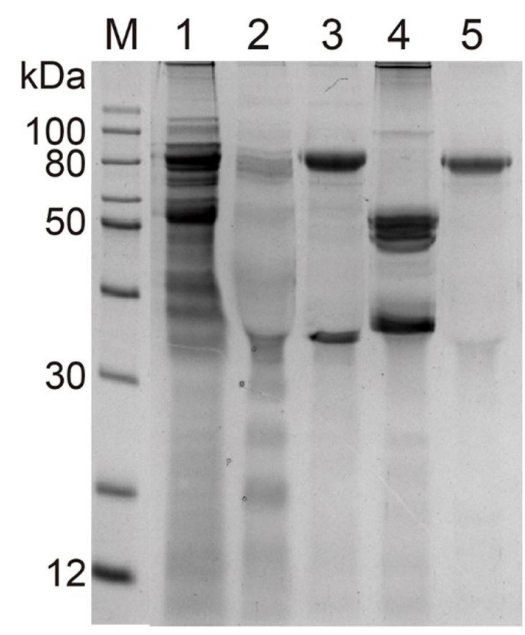

Figure 1. SDS-PAGE analysis of Strain B2, M: the standard protein molecular weight markers; (1) crude fermentation of Strain B2; (2) PB wash of DEAE-650C column; (3) $0.25 \mathrm{M} \mathrm{NaCl}$ in PBS elution of DEAE-650C column; (4) $1 \mathrm{M} \mathrm{NaCl}$ in PBS elution of DEAE-650C column; (5) PB by Sephacryl S-200 column.

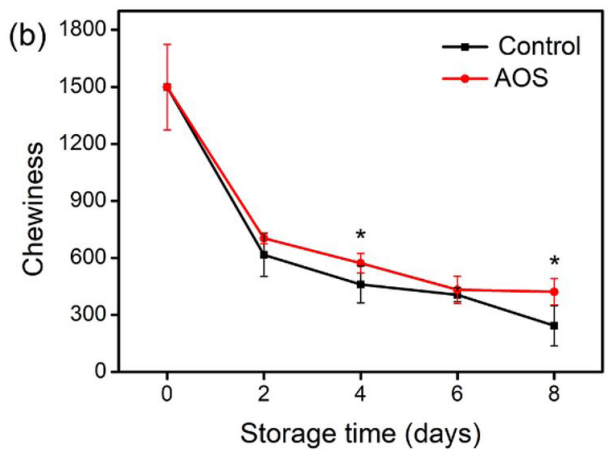

Figure 2. Texture changes of shrimp during cold storage, AOS: treated with alginate oligosaccharides; Control: treated with distilled water; each bar represents mean $\pm \mathrm{SD}$. ${ }^{\star} \mathrm{p}<0.05$, based on the Student's t-test, and significant differences can be seen for both treatments. (a) for hardness; (b) for chewiness.

Table 1. Changes of sensory scores in control group and AOS treated group.

\begin{tabular}{|c|c|c|c|c|c|}
\hline \multirow{2}{*}{ Treatment } & \multicolumn{5}{|c|}{ Storage time (days) } \\
\hline & 0 & 2 & 4 & 6 & 8 \\
\hline Control & $10 \pm 0.00$ & $8.56 \pm 0.42 \mathrm{ab}$ & $7.56 \pm 0.42 c$ & $5.81 \pm 0.26 \mathrm{~d}$ & $3.44 \pm 0.42 \mathrm{e}$ \\
\hline AOS & & $8.88 \pm 0.23 a$ & $8.38 \pm 0.35 b$ & $7.81 \pm 0.26 c$ & $6.06 \pm 0.32 \mathrm{~d}$ \\
\hline
\end{tabular}


chewiness of the AOS and water decreased over the 8 days period. However, the AOS treatment group had a higher hardness and chewiness compared to the control group. This result is similar to the results of other studies (Hsu et al., 2016; Feng et al., 2016; Huang et al., 2015). Overall, the chewiness of shrimp treated with AOS tended to be better than the control group. This is indicative that AOS coating was effective in improving the rheological properties of the treated shrimp. However, the hardness was not significantly higher in the AOS treatment compared to the control group and may be due to the low initial quality of shrimp used in our study.

\section{pH value}

The $\mathrm{pH}$ of the AOS treated shrimp was significantly lower compared to the distilled water control group during refrigerated storage $(\mathrm{p}<0.05)$ (Figure 3$)$. The AOS coated shrimp reached an acceptable level of $\mathrm{pH} 7.74$ on the 6th day. However, the $\mathrm{pH}$ of the control group approached 7.91 on the 6th day. This $\mathrm{pH}$ is designated as reaching the end of the stored shrimps shelf life and is consistent with the previous results (Galvão et al., 2017). There was a great relationship between the enzymes present in the shrimp tissues and the changes of microbial metabolites, which effected the $\mathrm{pH}$ of the sample. The increase in $\mathrm{pH}$ is attributed bacterial growth and protein decomposition by enzymes to produce basic compounds (Wu et al., 2014). The $\mathrm{pH}$ of the stored shrimp is also influenced by other factors, such as the type of fish and the growth environment. Therefore, $\mathrm{pH}$ of the sample can be used as a supplementary indicator to represent the quality of the stored shrimp.

\section{TVB-N}

Total volatile basic-nitrogen (TVB-N) is another major indicator of shelf life for seafood. In general, shrimp's TVB-N content increased over the time of refrigerated storage regardless of treatment. However, we found that the TVB-N content of shrimp treated with AOS was lower than that of the control group ( $<<0.05)$. As was shown in Figure 4, the final TVB-N content was about $23.3 \mathrm{mg} / 100 \mathrm{~g}$ for AOS coated shrimp, which is lower than reported by Bonilla et al. (2018). TVB-N content in the control group was approximately $30.3 \mathrm{mg} / 100 \mathrm{~g}$ at day 8 of storage. A limit TVB-N of $30 \mathrm{mg} / 100 \mathrm{~g}$ for shrimp products is usually regarded as spoiled. The above results are consistent with previous studies in which the TVB-N value of shrimp treated with a chitosan-carvacrol coating had been found to be significantly decreased (Wang et al., 2018). The results indicate, based off of TVB-N content of stored shrimp, that AOS coating can be used to extend the shelf life of shrimp by 2 days during storage.

\section{K-value}

Figure 5 shows the change in K-value of the two different treatments of shrimp during refrigeration. The K-value increased over time in both the AOS coated shrimp and the control group. The K-value of the AOS coated shrimp was lower $(\mathrm{p}<0.05)$ than the control group over the measured time period. As the storage time increases, many biochemical reactions occur in the stored shrimp that may affect freshness, including adenosine triphosphate (ATP) degradation to hypoxanthine. The increase in K-value was

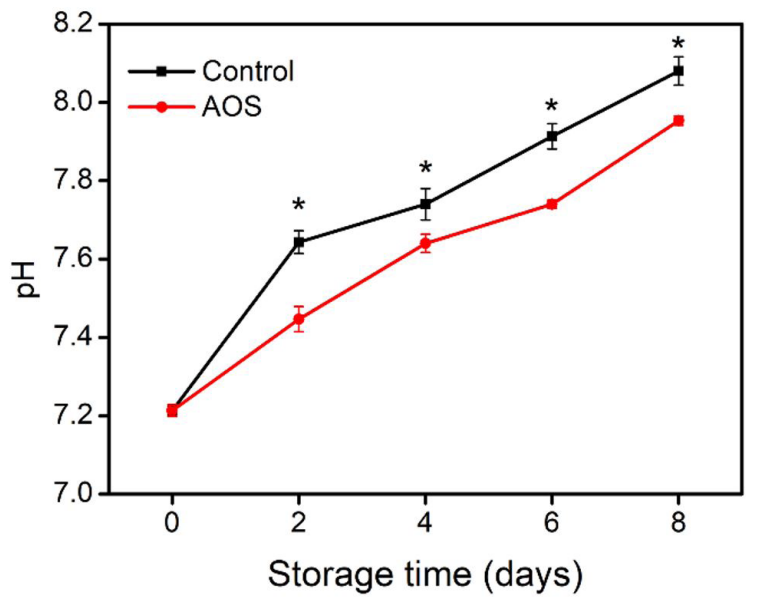

Figure 3. $\mathrm{pH}$ changes of shrimp during cold storage, AOS: treated with alginate oligosaccharides; Control: treated with distilled water; Each bar represents mean \pm SD. ${ }^{*} \mathrm{p}<0.05$, based on the Student's t-test, and significant differences can be seen for both treatments.

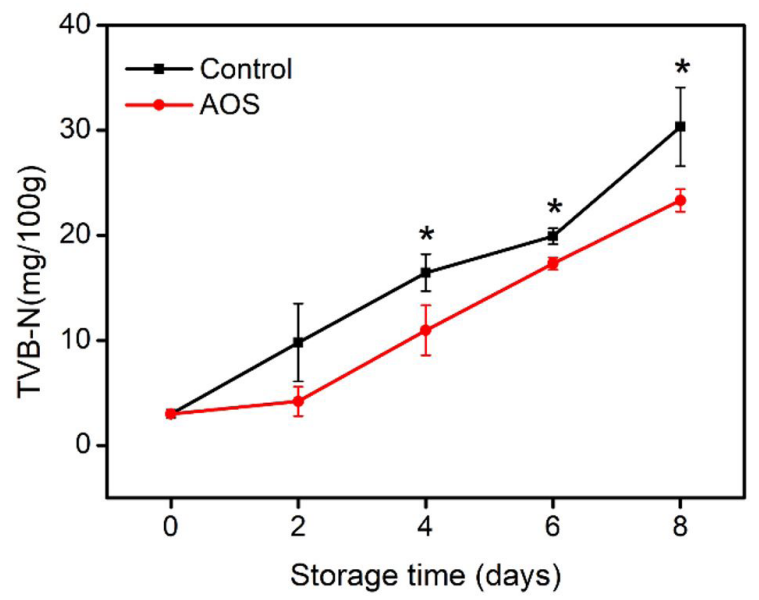

Figure 4. TVB-N content of shrimp during cold storage, AOS: treated with alginate oligosaccharides; Control: treated with distilled water; Each bar represents mean $\pm \mathrm{SD} .{ }^{*} \mathrm{p}<0.05$, based on the Student's t-test, and significant differences can be between both treatments.

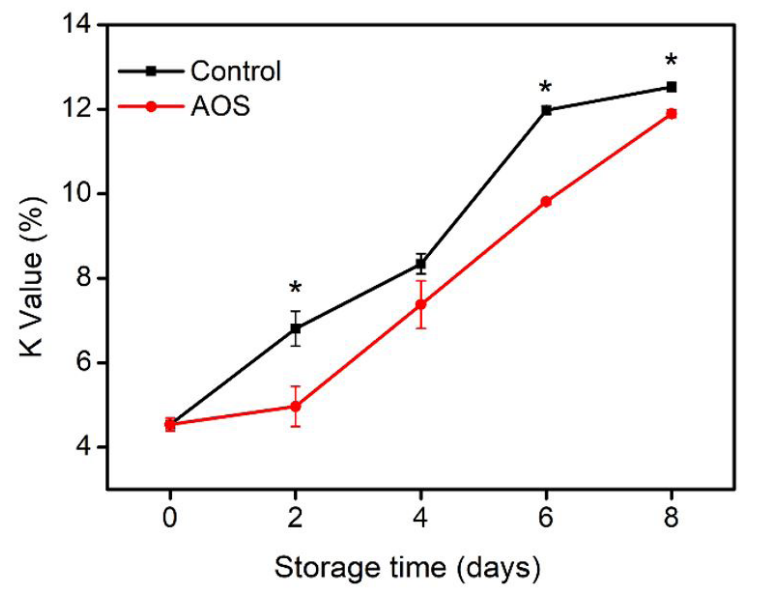

Figure 5. K-value changes of shrimp during cold storage, AOS: treated with alginate oligosaccharides; Control: treated with distilled water; Each bar represents mean $\pm S D$. ${ }^{\star} p<0.05$, based on the Student's t-test, and significant differences can be seen between both treatments. 


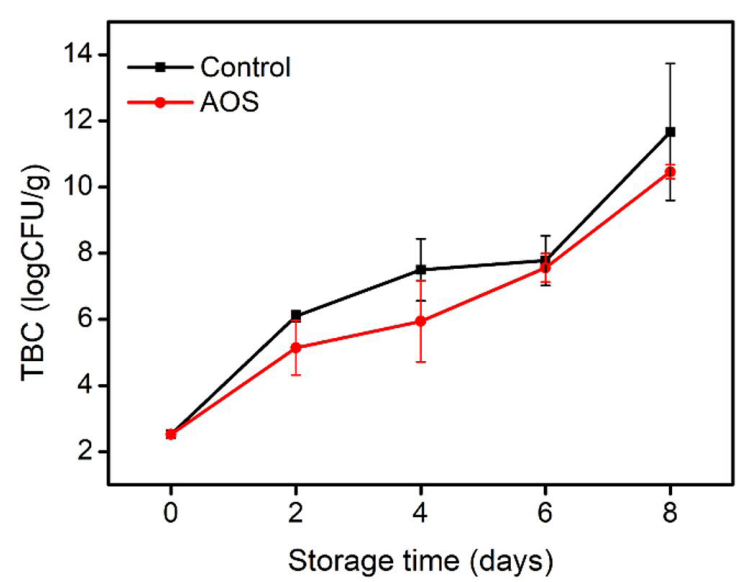

Figure 6. TBC number of shrimps during cold storage, AOS: treated with alginate oligosaccharides; Control: treated with distilled water; Each bar represents mean \pm SD. ${ }^{\star} p<0.05$, based on the Student's t-test, and significant differences can be seen for both treatments.

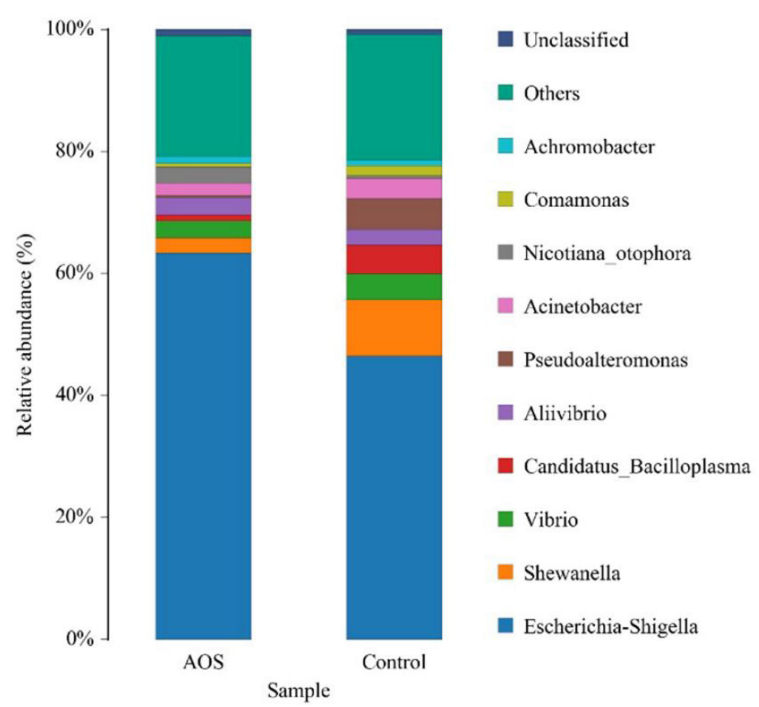

Figure 7. The main phylums of bacteria found in shrimp intestinal bacterial communities among different samples, AOS: treated with alginate oligosaccharides; Control: treated with distilled water.

associated with the accumulation of hypoxanthine and inosine, which can be attributed to enzyme action. AOS coating may reduce the rate of ATP degradation by inhibiting endogenous autolytic enzyme activity, which can increase the quality of shrimp during storage.

\subsection{Microbial analysis}

\section{Total Bacteria Count (TBC)}

During cold storage, the shelf life of seafood can be negatively affected due to bacterial growth. Shrimp lose market value due to the total bacteria count (TBC) exceeding spoilage level. The initial TBC of both the AOS coated and control groups was about $2.52 \log \mathrm{CFU} / \mathrm{g}$, indicating a high quality of the shrimp. This measurement is consistent with the results of the previous studies by Li et al. (2017) and Arancibia et al. (2015). The TBC of both groups gradually increased during storage, however the increase of TBC was slower in the AOS treatment compared to the control treatment (Figure 6). This may be due to AOS treatments potentially having antibacterial activity against Pseudomonas as reported in other studies using low molecular weight alginate oligomers (Pritchard et al., 2017b).

\section{Composition analysis of the intestinal microbial community}

Figure 7 shows differences in the intestinal microbial communities from both AOS treated shrimp and control groups. Our results show an obvious differences in the shrimp intestinal bacterial community between AOS treated group and the control group. Most bacteria found in the shrimp intestinal contents belonged to the phylum Escherrichia-Shigella, but it should be noted that bacteria from the phylum Shewanella and Pseudoalteromonas are major spoilage bacteria found on shrimp. The amount of bacteria from the Shewanella and Pseudoalteromonas phylum in AOS treated group was lower compared to the control group. Furthermore, cluster analysis indicates that AOS treatment changes the bacterial community structure, with bacteria from the Candidatus-Bacilloplasma phylum decreasing in AOS treated group. The data also revealed that bacteria from the Vibrio phylum was reduced after AOS treatment, which is widely found in shellfish.

The analysis also revealed changes in bacterial composition between AOS and control groups after 8 days of storage. The predominant bacteria found in seafood was bacteria from the Shewanella and Pseudoalteromonas phylums (Mejlholm \& Dalgaard, 2015; Serio et al., 2014; Ikutegbe \& Sikoki, 2014; Capita et al., 2018; Fu et al., 2018). AOS has been shown to have antibacterial activity (Pritchard et al., 2017a; Tøndervik et al., 2014; Xu et al., 2014b; Li et al., 2018). Moreover, the abundance of bacterial composition in samples varied greatly between the AOS treated shrimp and shrimp stored in distilled water. This emphasizes that AOS coating has considerable effects on the composition of the microbial community.

\section{Conclusions}

The results of this paper show that AOS coating can better increase the quality of white shrimp compared to untreated white shrimp. This is supported by AOS treatment not only maintaining better sensory scores and characteristics of texture but by also showing a higher capacity to inhibit microbial counts, a lower TVB-N formation, and a lowered $\mathrm{K}$-value and $\mathrm{pH}$ during storage. Therefore, AOS and similar kinds of biological preservative may have a vital effect on the preservation of future seafood.

\section{Acknowledgements}

The authors appreciate the financial support by the Program of Finance Department of Fujian Province in China (Grant No. (2014)1262), the Program of Finance Department of Fujian Province in China (Grant No. (2015)1297), the Program of Science and Technology of Fuzhou University in China (Grant No. 2014-XQ-20), the Program of Science and Technology of Fuzhou city in China (Grant No. 2017-G-66), "Thirteenth Five-Year Plan" Marine Economy Innovation and Development Demonstration Project (Grant No. FZHJ19). 


\section{References}

Alkawash, M. A., Soothill, J. S., \& Schiller, N. L. (2006). Alginate enzyme enhances antibiotic killing of mucoid Pseudomonas aeruginosa in biofilms. APMIS, 114(2), 131-138. http://dx.doi. org/10.1111/j.1600-0463.2006.apm_356.x. PMid:16519750.

Arancibia, M. Y., López-Caballero, M. E., Gómez-Guillén, M. C., \& Montero, P. (2015). Chitosan coatings enriched with active shrimp waste for shrimp preservation. Food Control, 54, 259-266. http:// dx.doi.org/10.1016/j.foodcont.2015.02.004.

Blackwood, L. L., Stone, R. M., Iglewski, B. H., \& Pennington, J. E. (1983). Evaluation of Pseudomonas aeruginosa exotoxin A and elastase as virulence factors in acute lung infection. Infection and Immunity, 39(1), 198-201. http://dx.doi.org/10.1128/IAI.39.1.198201.1983. PMid:6401692.

Bonilla, F., Chouljenko, A., Reyes, V., Bechtel, P. J., King, J. M., \& Sathivel, S. (2018). Impact of chitosan application technique on refrigerated catfish fillet quality. Lebensmittel-Wissenschaft + Technologie, 90, 277-282. http://dx.doi.org/10.1016/j.lwt.2017.12.010.

Boucelkha, A., Petit, E., Elboutachfaiti, R., Molinie, R., Amari, S., \& Yahaoui, R. Z. (2016). Production of guluronate oligosaccharide of alginate from brown algae Stypocaulon scoparium using an alginate enzyme. Journal of Applied Phycology, 29(1), 1-11.

Capita, R., Álvarez-González, T., \& Alonso-Calleja, C. (2018). Effect of several packaging conditions on the microbiological, physicochemical and sensory properties of ostrich steaks during refrigerated storage. Food Microbiology, 72, 146-156. http://dx.doi.org/10.1016/j. fm.2017.10.007. PMid:29407391.

Chen, K., Shao, L. L., Huo, Y. F., Zhou, J. M., Zhu, Q., Hider, R. C., \& Zhou, T. (2019). Antimicrobial and antioxidant effects of a hydroxypyridinone derivative containing an oxime ether moiety and its application in shrimp preservation. Food Control, 95, 157-164. http://dx.doi.org/10.1016/j.foodcont.2018.08.008.

Ci, S. X., Huynh, T. H., Louie, L. W., Yang, B., Beals, B. J., Ron, N., Tsang, W. G., Soon-Shiong, P., \& Desai, N. P. (1999). Molecular mass distribution of sodium alginate by high-performance size-exclusion chromatography. Journal of Chromatography. A, 864(2), 199-210. http://dx.doi.org/10.1016/S0021-9673(99)01029-8. PMid:10669287.

Erickson, M. C., Bulgarelli, M. A., Resurreccion, A. V. A., Vendetti, R. A., \& Gates, K. A. (2007). Sensory differentiation of shrimp using a trained descriptive analysis panel. Lebensmittel-Wissenschaft + Technologie, 40(10), 1774-1783. http://dx.doi.org/10.1016/j. lwt.2006.12.007.

Feng, J. M., Zhang, B., Jiang, L. Z., Wang, Q., Deng, S. G., \& Wang, L. L. (2016). Quality preservation of fresh shrimp (Litopenaeus vannamei) by employment of slurry ice in combination with bacteriostatic agent and melanosis inhibitor. Shipin Kexue, 37(2), 244-249.

Fu, L. L., Wang, C., Liu, N. N., Ma, A. J., \& Wang, Y. B. (2018). Quorum sensing system-regulated genes affect the spoilage potential of Shewanella baltica. Food Research International, 107, 1-9. http:// dx.doi.org/10.1016/j.foodres.2018.01.067. PMid:29580465.

Galvão, J. A., Vázquez-Sánchez, D., Yokoyama, V. A., Savay-Da-Silva, L. K., Brazaca, S. G. C., \& Oetterer, M. (2017). Effect of 4-hexylresorcinol and sodium metabisulphite on spoilage and melanosis inhibition in Xiphopenaeus kroyeri shrimps. Journal of Food Processing and Preservation, 41(3), e12943. http://dx.doi.org/10.1111/jfpp.12943.

Gonçalves, A., \& Gindri, C. S. G. Jr. (2009). The effect of glaze uptake on storage quality of frozen shrimp. Journal of Food Engineering, 90(2), 285-290. http://dx.doi.org/10.1016/j.jfoodeng.2008.06.038.
Haug, A., Larsen, B., \& Smidsrød, O. (1974). Uronic acid sequence in alginate from different sources. Carbohydrate Research, 32(2), 217 225. http://dx.doi.org/10.1016/S0008-6215(00)82100-X.

He, X., Hwang, H. M., Aker, W. G., Wang, P., Lin, Y. F., Jiang, X. L., \& He, X. Y. (2014). Synergistic combination of marine oligosaccharides and azithromycin against Pseudomonas aeruginosa. Microbiological Research, 169(9-10), 759-767. http://dx.doi.org/10.1016/j.micres.2014.01.001. PMid:24529598.

Hsu, W. H., Lai, Y. J., \& Wu, S. C. (2016). Effects of the anti-microbial peptide pardaxin plus sodium erythorbate dissolved in different gels on the quality of Pacific white shrimp under refrigerated storage. Food Control, 73, 712-719. http://dx.doi.org/10.1016/j. foodcont.2016.09.025.

Hu, X. K., Jiang, X. L., Hwang, H., Liu, S. H., \& Guan, H. S. (2004). Antitumour activities of alginate-derived oligosaccharides and their sulphated substitution derivatives. European Journal of Phycology, 39(1), 67-71. http://dx.doi.org/10.1080/09670260310001636695.

Huang, J., Ding, C., Xie, C., Lin, L., Yu, Q. D., \& Li, G. F. (2015). Impact of alginate oligosaccharide on peru squid minced fish quality characteristics. Oceanologia et Limnologia Sinica, 46(3), 659-664.

Ikutegbe, V., \& Sikoki, F. (2014). Microbiological and biochemical spoilage of smoke-dried fishes sold in West African open markets. Food Chemistry, 161(11), 332-336. PMid:24837959.

Iwamoto, M., Kurachi, M., Nakashima, T., Kim, D., Yamaguchi, K., Oda, T., Iwamoto, Y., \& Muramatsu, T. (2005). Structure-activity relationship of alginate oligosaccharides in the induction of cytokine production from RAW264.7 cells. FEBS Letters, 579(20), 4423-4429. http://dx.doi.org/10.1016/j.febslet.2005.07.007. PMid:16055120.

Johnson, F. A., Craig, D. Q., \& Mercer, A. D. (1997). Characterization of the block structure and molecular weight of sodium alginates. The Journal of Pharmacy and Pharmacology, 49(7), 639-643. http:// dx.doi.org/10.1111/j.2042-7158.1997.tb06085.x. PMid:9255704.

Kawada, A., Hiura, N., Shiraiwa, M., Tajima, S., Hiruma, M., Hara, K., Ishibashi, A., \& Takahara, H. (1997). Stimulation of human keratinocyte growth by alginate oligosaccharides, a possible cofactor for epidermal growth factor in cell culture. FEBS Letters, 408(1), 43-46. http://dx.doi.org/10.1016/S0014-5793(97)00386-4. PMid:9180265.

Li, T., Wang, D. F., Liu, N., Ma, Y., Ding, T., Mei, Y. C., \& Li, J. R. (2018). Inhibition of quorum sensing-controlled virulence factors and biofilm formation in Pseudomonas fluorescens by cinnamaldehyde. International Journal of Food Microbiology, 269, 98-106. http://dx.doi. org/10.1016/j.ijfoodmicro.2018.01.023. PMid:29421365.

Li, Y. C., Yang, Z. Y., \& Li, J. R. (2017). Shelf-life extension of Pacific white shrimp using algae extracts during refrigerated storage. Journal of the Science of Food and Agriculture, 97(1), 291-298. http://dx.doi. org/10.1002/jsfa.7730. PMid:27013186.

Mastromatteo, M., Incoronato, A. L., Conte, A., \& Del Nobile, M. A. (2011). Shelf life of reduced pork back-fat content sausages as affected by antimicrobial compounds and modified atmosphere packaging. International Journal of Food Microbiology, 150(1), 1-7. http://dx.doi. org/10.1016/j.ijfoodmicro.2011.07.009. PMid:21820750.

Mejlholm, O., \& Dalgaard, P. (2015). Modelling and predicting the simultaneous growth of Listeria monocytogenes and psychrotolerant lactic acid bacteria in processed seafood and mayonnaise-based seafood salads. Food Microbiology, 46, 1-14. http://dx.doi.org/10.1016/j. fm.2014.07.005. PMid:25475260.

Miura, R., Ethell, I. M., \& Yamaguchi, Y. (2001). Carbohydrate-protein interactions between HNK-1-reactive sulfoglucuronyl glycolipids and the proteoglycan lectin domain mediate neuronal cell adhesion 
and neurite outgrowth. Journal of Neurochemistry, 76(2), 413-424. http://dx.doi.org/10.1046/j.1471-4159.2001.00042.x. PMid:11208904.

Natsume, M., Kamo, Y., Hirayama, M., \& Adachi, T. (1994). Isolation and characterization of alginate-derived oligosaccharides with root growth-promoting activities. Carbohydrate Research, 258(6), 187-197. http://dx.doi.org/10.1016/0008-6215(94)84085-7. PMid:8039175.

Pritchard, M. F., Jack, A. A., Powell, L. C., Sadh, H., Rye, P. D., Hill, K. E., \& Thomas, D. W. (2017a). Alginate oligosaccharides modify hyphal infiltration of Candida albicans in an in vitro model of invasive human candidosis. Journal of Applied Microbiology, 123(3), 625-636. http://dx.doi.org/10.1111/jam.13516. PMid:28635170.

Pritchard, M. F., Powell, L. C., Jack, A. A., Powell, K., Beck, K., Florance, H., Forton, J., Rye, P. D., Dessen, A., Hill, K. E., \& Thomas, D. W. (2017b). A low molecular weight alginate oligosaccharide disrupts pseudomonal microcolony formation and enhances antibiotic effectiveness. Antimicrobial Agents and Chemotherapy, 61(9), e0076217. http://dx.doi.org/10.1128/AAC.00762-17. PMid:28630204.

Rahman, M. M., Inoue, A., Tanaka, H., \& Ojima, T. (2010). Isolation and characterization of two alginate enzyme isozymes, AkAly28 and AkAly33, from the common sea hare Aplysia kurodai. Comparative Biochemistry and Physiology. Part B, Biochemistry \& Molecular Biology, 157(4), 317325. http://dx.doi.org/10.1016/j.cbpb.2010.07.006. PMid:20708706.

Sawabe, T., Ezura, Y., \& Kimura, T. (1993). Application of an alginate enzyme from Alteromonas sp. for isolation of protoplasts from a brown algae laminaria japonica. Nippon Suisan Gakkaishi, 59(4), 705-709. http://dx.doi.org/10.2331/suisan.59.705.

Serio, A., Fusella, G. C., Chaves López, C., Sacchetti, G., \& Paparella, A. (2014). A survey on bacteria isolated as hydrogen sulfide-producers from marine fish. Food Control, 39(1), 111-118. http://dx.doi. org/10.1016/j.foodcont.2013.11.003.

Singh, R. P., Gupta, V., Kumari, P., Kumar, M., Reddy, C. R. K., Prasad, K., \& Jha, B. (2011). Purification and partial characterization of an extracellular alginate enzyme from Aspergillus oryzae isolated from brown seaweed. Journal of Applied Phycology, 23(4), 755-762. http:// dx.doi.org/10.1007/s10811-010-9576-9.

Tøndervik, A., Sletta, H., Klinkenberg, G., Emanuel, C., Powell, L. C., Pritchard, M. F., Khan, S., Craine, K. M., Onsøyen, E., Rye, P. D., Wright, C., Thomas, D. W., \& Hill, K. E. (2014). Alginate oligosaccharides inhibit fungal cell growth and potentiate the activity of antifungals against Candida and Aspergillus spp. PLoS One, 9(11), e112518. http://dx.doi.org/10.1371/journal.pone.0112518. PMid:25409186.

Wang, Q. Y., Lei, J., Ma, J. J., Yuan, G. F., \& Sun, H. Y. (2018). Effect of chitosan-carvacrol coating on the quality of Pacific white shrimp during iced storage as affected by caprylic acid. International Journal of Biological Macromolecules, 106, 123-129. http://dx.doi. org/10.1016/j.ijbiomac.2017.07.180. PMid:28778523.

Wang, Y., Guo, E. W., Yu, W. G., \& Han, F. (2013). Purification and characterization of a new alginate enzyme from a marine bacterium Vibrio sp. Biotechnology Letters, 35(5), 703-708. http://dx.doi. org/10.1007/s10529-012-1134-x. PMid:23299986.

Wu, Y. Y., Sun, J. Y., Yang, X. Q., Ma, H. X., Huang, H., \& Ceng, J. W. (2014). Analysis of quality on modified atmosphere packaged cobia fillet during freezing-point storage. Xiandai Shipin Keji, 30(8), 117-124.

Xu, L. L., Hu, P. P., Kong, X. L., Hider, R. C., Zhou, T., \& Dai, Z. Y. (2014a). 3-Hydroxypyridinone- L -phenylalanine conjugates with antimicrobial and tyrosinase inhibitory activities as potential shrimp preservatives. International Journal of Food Science \& Technology, 49(3), 797-803. http://dx.doi.org/10.1111/ijfs.12367.

Xu, X., Bi, D., Wu, X. T., Wang, Q. Q., Wei, G. B., Chi, L. L., Jiang, Z., Oda, T., \& Wan, M. (2014b). Unsaturated guluronate oligosaccharide enhances the antibacterial activities of macrophages. The FASEB Journal, 28(6), 2645-2654. http://dx.doi.org/10.1096/fj.13-247791. PMid:24599964. 